\title{
Human-etisk forbunds omsorgstjeneste
}

\author{
V ed Kitty Larsgaard
}

\section{Human-Etisk/Forbund}

Human-Etisk Forbund (HEF) er en organisasjon av og for mennesker som ikke er bundet av noen religion. Vi bygger vårt livssyn og vår etikk på medmenneskelighet, personlig erfaring, egen kritisk tenkning og idealene i FNs menneskerettigheter. Forbundet er partipolitisk uavhengig. HEF mener at offentlige lett tilgjengelige, liussynsnøytrale og profesjonelle omsorgstilbud for alle innbyggere er en grunnleggende forutsetning i et velferdssamfunn. Tilbud fra frivillige organisasjoner er et viktig supplement. I og med at det ikke finnes liussynsnøytrale tjenester så mange steder, ønsker HEF å bygge opp en egen omsorgstjeneste der man kan tilby liussynstjenester som inkluderer samtaler med bl.a. mennesker som er $i$ sorg eller krise.

\section{Omsorgstjenesten}

H uman-Etisk Forbunds omsorgsutvalg i A kershus og 0 slo ble etablert i juni 1996. I denne perioden har det pågått en utprøving av arbeidsmåter og organiseringsmåter for å drive omsorgsarbeid som et systematisk tiltak i regi av HEF. Dette har vakt interesse både in nenfor og utenfor forbundet. Flere steder i landet har medlemmer engasjert seg i frivillig omsorgs- og støttearbeid. Det er etablert ulike tilbud i Buskerud, Stavanger, Trondheim, Bergen, Telemark og Finnmark (A Ita). I M øre og R omsdal planlegges det start høsten 2000. 0 msorgstilbudet er åpent for alle.

\section{Støttepersonene}

V åre støttepersoner tilbyr medmenneskelig assistanse bygget på egne erfaringer. I tillegg gjennomgår de kurs arrangert av $H$ uman-Etisk Forbund. Støttepersonene får hele tiden oppføl ging, og de har et faglig støtteapparat i ryggen. Bl.a. får de opplæring og hjelp i å henvise brukere til ulike deler av det profesjonelle hjelpeapparatet når de forstår at brukerne trenger mer enn den formen for støtte de selv kan tilby. Støttepersonene har en annen rolle enn behandlere. De har også en annen rolle enn en nabo, slektning, venn eller kollega, og er forberedt på den situasjonen de går inn $\mathrm{i}$.

Det personlige engasjementet som frivillige støttepersoner går inn $i$ arbeidet med, er sammen med egen livserfaring en stor ressurs.

Støttepersonenes oppgave er ikke å være «hobbypsykologer», men å fungere som medmennesker som vektlegger aktiv lytting og å være der for mennesker som ikke vet hvor de ellers skal henvende seg.

\section{Støttetelefonen}

Støttetelefonen ble etablert våren 98. Fra høsten 1999 er telefonen betjent hver dag fra kl. 17.00 til 22.00. Vi har henven- delser fra hele landet, fordi ikke alle fylkeslag har omsorgsutvalg. Å rsakene til henvendel sene varierer, men depresjoner, angst og selvmordstanker går ofte igjen. I tillegg er det mennesker som ønsker å snakke med et annet menneske - de er "lei av hvite frakker og det offentlige tilbudet", som de synes er mangelfullt. N oen har også vært gjennom hjelpeapparatet, men har ikke opplevd å bli forstått, respektert eller hjulpet.

\section{Støttegrupper}

Tilbudet om støttegrupper bygger på en modell utviklet bl.a. av prosjektet Sorg og 0 msorg. Ideen er at når personer med sammenlignbare krise- eller sorgopplevelser kommer sammen og snakker om sine opplevelser, utløses ressurser i gruppen som kan hjelpe deltakerne i arbeidet med å til passe seg en ny livssituasjon eller overvinne en sorgreaksjon. M en erfaringer viser også at heterogene grupper kan fungere veldig bra. Våre støttepersoner fungerer som gruppeledere. Deres oppgave er praktisk tilrettelegging og å påse at gruppeprosessen kommer igang.

\section{Individuelle samtaler}

De kan foregå enten på kontoret, i sykehus eller $\mathrm{i}$ et fengsel. Innholdet i samtalen bestemmes av hjel psøkeren. $V$ åre støttepersoners rolle er å være lyttende og gi hjel psøkeren tid til å være reflekterende i forhold til det tema som berøres.

\section{Økende etterspørsel}

Vi har merket en økende etterspørsel etter sorggrupper og individuelle samtaler, spesielt fra foreldre som har mistet barn i selvmord. Å rsaken til at de henvender seg til oss er forskjellige, men ofte hører vi at de synes de har fått for lite oppfølging fra det offentlige etter tragedien. $M$ ange ønsker et livssynsåpent tilbud. N oen har også gitt uttrykk for at de synes det er vanskeligå snakke åpent i en gruppe med folk som har et religiøst livssyn. De har problemer med utsagn som: "G ud hadde en mening med dette".

Bruken av våre omsorgstjenester til nå gir en klar bekreftelse på at det er behov for dette tilbudet, ikke minst i forhold til mennesker med selvmordstanker. I opplæringen av støttepersoner vil det bli lagt vekt på selvmordsproblematikk. Tendensen tyder på at etter hvert som HEFs omsorgstilbud blir mer brukt og bedre kjent, vil antall henvendelser øke. Tilbudet er kommet for å bli. Et supplement til religiøse organi sasjoner og offentlige institusjoner er en nødvendighet $\mathrm{i}$ dagens mangfoldige samfunn.

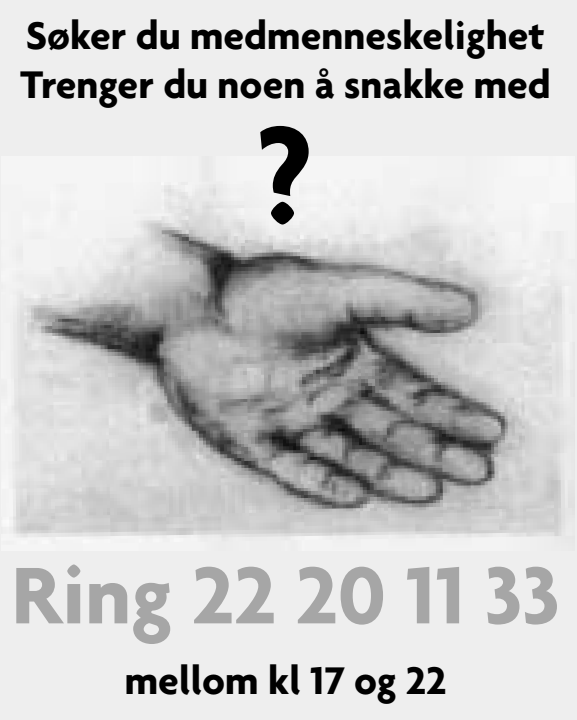

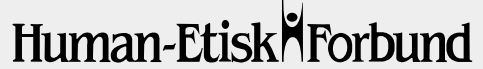

Kitty L arsgaard arbeider som organisasjonssekretær i H EF, A kershus fylkeslag, og har vært omsorgsutval gets sekretær/koordinator siden starten i 1996. I tillegg er hun støttekontakt i det offentlige og frivillig støtteperson i HEF, med erfaring fra individuelle samtaler, sykehusbesøk, oppfølging av pårørende m.m. 